\title{
The Role of Polish Crowdfunding Platforms in Film Productions - an Exploratory Study
}

\author{
Urszula Świerczyńska-Kaczor \\ The Jan Kochanowski University \\ in Kielce \\ ul. Żeromskiego 15, \\ 25-369 Kielce, Poland \\ Email: swierczynska@ujk.edu.pl
}

\author{
Paweł Kossecki \\ Paweł Kossecki \\ The Lodz Film School, \\ ul. Targowa 61/63, \\ 90-323 Lodz, Poland, \\ E-mail: kossecki@poczta.onet.pl
}

\begin{abstract}
This paper aims to contribute to the better understanding, and in consequence, better development and implementation of crowdfunding projects for filmmaking. This study covers two areas of analysis: project-level research and founders-level (creators-level) research. In the first area, the article presents an analysis of documentary film projects based on descriptive statistics and the clustering of the film projects. In the second area, the paper sheds light on the Polish filmmakers' attitude to crowdfunding, and this analysis was based on a survey. This exploratory study led to the following conclusions: 1. The descriptive statistics indicate that the 'average documentary film' on the Polish market reaches a higher level of funding compared to non-documentary projects, and higher numbers of supporters. 2. The film projects on the Polish crowdfunding platforms can be segmented into six clusters. 3. The survey conducted among Polish filmmakers indicates that the experts strongly differed in their views about crowdfunding in general, and specifically, in the crowdfunding for documentary films. Such diversity of opinions and attitudes may be linked to the novelty of crowdfunding and therefore, the experts' difficulty of assessing the present and future role of crowdfunding for filmmaking. 4. This study shows that over $\mathbf{8 5 \%}$ of experts agree with the sponsor's involvement with film production. Such a high level of expert agreement is important as nowadays 'being a prosumer' is one of the major trends of consumer behavior.
\end{abstract}

\section{INTRODUCTION}

$\mathrm{T}$ HE magnitude of crowdfunding has been steadily growing: in 2014 the global total volume of funding was about 16.2 billion US\$ compared to 0.8 billion US\$ in 2010 (Belleflamme, Omrani, \& Peitz, 2015), the European Commission recorded the growth of crowdfunding platforms from 445 million euro in 2011 to 1 billion euro in 2013 (Borello, De Crescenzo, \& Pichler, 2015), and World Bank predicts that crowdfunding will reach 93 billion US\$ by 2025 (Kshetri, 2015). Although, crowdfunding covers very different kinds of projects, the cultural industries, such as film, music and video games have been taking a large share of the crowdfunding market (Boeuf, Darveau, Legoux, 2014). Major crowdfunding platforms gather thousands of artistic projects, e.g. on 1 May 2016, on Kickstarter there were over 294 thousand projects in all artistic categories, nearly 55 thousand projects in the category of video/film, and within this category over 600 'live' projects (kickstarter.com, 01.05.206).

In Poland crowdfunding is still in the very early stages of introduction to possible adopters, both to funders (called also sponsors or backers) and founders (project creators). So far, Polish crowdfunding platforms have attracted a relatively small group of users, for example, on 2 May, 2016 the crowdfunding platform polakpotrafi.pl reported 2263 projects in all categories (polakpotrafi.pl, 02.05.2016). However, we presume that the near future would bring further expansion of crowdfunding on the Polish market due to various factors, for instance, diminishing barriers for Internet payment and growing user knowledge about crowdfunding.

The academic research of crowdfunding is still in the nascent stage, especially if we consider the research conducted in a part of a particular domain, e.g. the crowdfunding for disruptive innovations, or the crowdfunding for art and cultural events. This article aims to fill the gap in the understanding of crowdfunding in the domain of film production. In this study we particularly focus on crowdfunding projects linked to documentary films.

The paper is structured as follows: in the next section we discuss the research problem and the scope of the conducted analyses, and then we present the context of research. The third section focuses on the analysis of the documentary films on selected crowdfunding platforms (Kickstarter, polakpotrafi.pl, and wispieramkulture.pl). This overview of the film projects is followed by a presentation of the results of a survey conducted among Polish filmmakers. Finally, the last part of the article highlights the conclusions, and future research. 


\section{THE RESEARCH PROBLEM}

\section{A. The scope of research}

Our research aims to contribute to better understanding the process of film crowdfunding, with particular focus on documentary films and the Polish filmmaking industry. In this article, we present a study conducted in the following two areas:
A. the overview of the film and documentary film projects on selected crowdfunding platforms;
B. the Polish filmmakers' attitudes to crowdfunding;

\section{B. Overview of film and documentary film projects on the selected crowdfunding platform}

The idea of crowdfunding began from the crowdfunding of small-scale music and film projects (Hörisch,2015). Nowadays, it seems that crowdfunding covers almost all kinds of human activities (from art, technology, medicine, scientific discovery to film production), and crowdfunding projects significantly vary in time duration (from 'one-time' events to projects enabling the expansion of business ventures). In literature, crowdfunding is classified into four different models (see - Ryu \& Kim, 2016; Lam, \& Law, 2016), although in practice crowdfunding can be based on their variations (see - Vasileiadou, Huijben, \& Raven, 2015). The main crowdfunding models are: donation-based crowdfunding, lending-based crowdfunding, reward-based crowdfunding, and equity-based crowdfunding.

The majority of the film projects are based on a rewardbased crowdfunding in which the funders receive different kinds of rewards as compensation for their support. In some situations, funders make a very small donation (for example, $5 \mathrm{zl}$ ) without even expecting a reward at all (donation-based crowdfunding). In most projects, the creator of the project (the founder) offers the film (DVD or online viewing) as a reward, therefore film crowdfunding can be perceived as pre-ordering the product by the potential audience. The creator often encourages the crowdfunders to participate and co-create the final product (e.g. playing parts in the film), and therefore the crowdfunder acts as a prosumer.

Apart from financing the project, crowdfunding can play other roles, for example being a way of promotion or a tool of validating the potential market for ideas (Hörisch, 2015). These two roles can be noticed also in film projects, as crowdfunding can bring public attention to a particular movie production (promotion role), and - if the project fails in funding - it may be a signal that the idea was not properly developed (the validation).

The knowledge of the project creator in how to develop the project, (for example, what level of financing is feasible, how to reward the backers), is crucial for enhancing the project's probability to meet the financial goal (the requested financial support). On many reward-based crowdfunding platforms (e.g. Kickstarter.com or polakpotrafi.pl) if the project does not meet the threshold of funding, the money returns to the backers, therefore reaching the financial threshold for each project determines the project's actual execution. Any crowdfounder must consider that many factors may constitute the success or failure of crowdfunded projects, for example: the entrepreneur's social capital (see - Zheng et al., 2014), the entrepreneur's network of close contacts (Mendes-Da-Silva et. al, 2016), the way in which the project demonstrates its legitimacy (Frydrych et al., 2014), or the level of required funding, the time of project duration, and its contribution frequency from sponsors (Cordova, Dolci, \& Gianfrate, 2015).

This study focuses on the analysis of crowdfunding for documentary film projects on the Polish market. To what extent does the funding of these film projects vary? Do most projects aim for very high or low funding? What is the 'average' level of funding, or number of sponsors?

To analyze crowdfunding for filmmaking we gathered the data from two selected Polish reward-based crowdfunding platforms - polakpotrafi.pl and wspieramkulutre.pl. The analyses were based on the descriptive statistics and KMeans analysis aiming to identify the clusters of film projects. To better understand the features of Polish crowdfunding compared to global platforms, we also conducted an analysis of selected documentary film projects on Kickstarter.

\section{The filmmakers' attitudes to crowdfunding}

The future of crowdfunding for films is, and will be, affected by the filmmakers' knowledge and attitude to the crowdfunding phenomenon. How do the professional filmmakers perceive the role of crowdfunding? What kind of barriers do they perceive for film crowdfunding? Do they agree with sponsor participation and film co-creation as a possible reward? In what way do experts assess the probability of success for documentary films? We looked for the answers by conducting a survey among the professionals. In April 2016, 37 respondents - Polish film producers and students of film production - took part in the survey, and filled in a questionnaire. As film production students are more likely to seek new funding sources compared to well-known producers, the opinion of this group is especially interesting and can be an indicator of crowdfunding development in the near future.

\section{THE CONTEXT OF RESEARCH}

In this section of the article, we would like to point to the following aspects of crowdfunding: the type of crowdfunding platforms, the sponsors, and developing the reward options. 


\section{A. Type of crowdfunding platforms}

To date, equity-based crowdfunding (in which the founders agree on sharing the profit) is much less popular and takes a much smaller part of the crowdfunding market than reward-based crowdfunding, however, its popularity may grow in future (Son Turan, 2015). With reference to filmmaking, we would like to point to the following two examples:

- British film project - The Age of Stupid - in which the profits were pledged to crowdfunders (Belleflamme, Lambert, \& Schwienbacher, 2014).

- CinemaShares.com - the crowdfunding platform which allows movie fans to buy shares of film projects (see https://cinemashares.com, 02.05.2016).

\section{B. The sponsors}

Drivers and deterrents of crowdfunding differ from the perspective of the creator, funder (sponsor) and crowdfunding platforms (see - Kuti, \& Madarász, 2014/3). So far, there is little knowledge about the specific sponsors' needs, behavior, motivation or characteristics in crowdfunding for filmmaking.

The study of Ryu, \& Kim (2016) is helpful in the understanding of the film crowdfunders' characteristics, although the study covers different kinds of projects (not only films). The authors identified four types of crowdfunding sponsors, which are named descriptively as 'angelic backers', 'reward hunters', 'avid fans' and 'tasteful hermits'. These identified clusters of sponsors differ not only in their characteristics (for example, the value of philanthropic and reward motivation), but also they tend to pledge money at different stages of the project life-cycle: from project launching to project closing. Ryu, \& Kim (2016) also pointed out that the project genre determines what kind of sponsor group is attracted, and the authors stated that "[a]ngelic backers tended to support films, plays, and charity projects, while reward hunters were more focused on art and design and game projects" (p. 49). The study of Galuszka, \& Bystrov (2014) which refers to the music industry, showed that the sponsor's motivation is not only connected with financial reward, but also to the willingness to support their favorite artists or the fandom.

Another important aspect is the viewer's satisfaction. In this field, the research of $\mathrm{Xu}$ et al. (2016) can bring an interesting insight, although again, the study embraces different types of projects (not necessarily films). Xu et al. (2016) examined the sponsor's satisfaction, and the ascendant factors from an asymmetrical perspective and configurational models. The authors pointed to the role of project implementation perspective, project novelty, sponsor participation, entrepreneur activeness and sponsor demographics as the important variables influencing sponsor satisfaction.

\section{Developing the rewards options}

Thürridl, \& Kamleitner (2016) examined different types of rewards in the crowdfunding (in general, not only film), indicating their important features, such as purpose/reward type, tangibility, scarcity, geographical location, monetary value/reward tier, recognition, level of collaboration, and the core future. Their study showed that the most popular strategies of rewarding sponsors in the film category are 'Add-On Highly Appreciated' and 'Top it Up'. In 'Top it Up' the rewards accumulate when a sponsor selects more valuable options, for example: for selecting the first tier the sponsor receives a 'thank you e-mail', but the second tier includes the reward from the first option, and additional benefits e.g. DVD film copy. 'Add-On Highly Appreciated' strategy underlines the value of the recognition of sponsor contribution to the project, for example, the filmmaker puts the name of the sponsor in the film credits.

In many cases of film crowdfunding, the crowdfunders pre-order the final product as a reward, which means that they take the risk that the film (final product) would not meet their expectations or the film would not be produced at all. Although fraud is possible in crowdfunding, the study conducted by Mollick (2014) indicates that very few projects failed to deliver the promised products, although delivery was often late. Some crowdfunding platforms, e.g. the crowdfunding platform Seed\&Spark, offer the possibility to see the accepted movies on its website (https://www.seedandspark.com/, 03.05.2016), which may be a factor in enhancing the sponsor's trust to the founder.

\section{THE OVERVIEW OF THE DOCUMENTARY FILMS ON CROWDFUNDING PLATFORMS}

\section{A. Global crowdfunding platform - kickstarter.com}

Kickstarter is one of the major reward-based crowdfunding platforms, at the time of writing, for creators from the US, the UK, Canada, Australia, New Zealand, the Netherlands, Denmark, Ireland, Norway, Sweden, Germany, France, Spain, Italy, Austria, Belgium, Switzerland, and Luxembourg. In order to overview the characteristics of the documentary film projects on kickstarter.com, we looked into data from two samples:

a. Sample 1 - On 13 April 2016 the search engine on kickstarter.com showed 14920 projects classified as "documentary projects in film/video on Earth'. For further analysis, we selected 100 projects using, as the criterion, 'the end day' - the first listed project will end in 2 hours, the last project will end in 19 days. In the next step, from this list we selected 19 projects which had reached the level of successful funding at the moment of sampling (note -1 . as some of these 19 successful projects still had a few more 
days for running, the actual funding for these projects may be higher than we captured in our sample; 2 . other projects from our sample list may well reach the level of funding in the next few days, but as they were not successful at the moment of sampling we did not include them for further analysis)

b. Sample 2 - On 1 May, 2016, the search engine of the Kickstarter.com platform showed 15014 projects categorized as 'documentary projects in film/video on Earth'. In the next step, we entered in search the criterion of 'the most funded', and we sampled the 10 top projects.

The most funded documentary film project (sample 2) gathered over 1 mil US\$ with support from over 8500 backers (see Tab. I). The average funding for the top ten projects was over 476 thousand dollars with support from over 7 thousand backers. The top ten projects raised over 4.7 mil US\$ altogether.

The 19 successful documentary projects analyzed from sample 1 raised US\$ 240994 altogether, with the average project receiving over 16 thousand dollars due to attracting over 160 backers. The overfunding for the 19 projects was $52 \%$ on average, meaning that the average project received more than one and a half times the funding that the founders applied for. Moreover, the 'average project' from the 'top 10' was overfunded by more than two times.

\section{B. Polish crowdfunding platforms - polakpotrafi.pl and wspieramkulture.pl}

For the analysis of Polish crowdfunding, we looked into the projects listed on two platforms: polakpotrafi.pl and wspieramkulture.pl. We gathered the data about the successful projects categorized as a film (on wspieramkulture.pl) or video/film (on polakpotrafi.pl), which were listed on these platforms in April 2016. It led to the analysis of 29 successful projects on wspieramkulture.pl and 108 successful projects on polakpotrafi.pl. In the next step of analysis, we classified 41 (38\%) projects of the 108 projects as documentary films on polakpotrafi.pl, and 6 projects $(21 \%)$ of the 29 projects as documentary films on wspieramkulture.pl. As the documentary films could have different features, we adopted a 'soft' approach for classification - taking as the main criterion to what extent the film is based on facts.

Our analysis was focused on two groups of projects in the film category: the documentary film vs non-documentary projects (for example: music video, fiction film). Tab. II presents the general overview of the documentary projects compared to the non-documentary projects on both Polish platforms. Average documentary film projects received funding of over 14 thousand złotych on the polakpotrafi platform, and nearly 16 thousand złotych on the wspieramkulure platform. The average documentary film project gathered the about 130 supporters. The statistics indicate a high level of diversification of projects, and a higher level of support for the documentary film projects compared to other film projects.

In order to identify the clusters for analyzed projects listed on polakpotrafi.pl, we used the following variables in the K-Means analysis:

a. The type of film project: documentary or nondocumentary;

b. The level of overfunding the project received. The projects vary on the level to which the actual funding exceeded the financial threshold. We categorized the film projects into three categories based on the ratio 'the actual

TABLE I.

THE DESCRIPTIVE STATISTICS OF ANALYZED PROJECTS - KICKSTARTER.COM

\begin{tabular}{|c|c|c|c|c|c|c|c|c|}
\hline & \multicolumn{4}{|c|}{$\begin{array}{l}19 \text { successful projects from the } 100 \text { projects taken } \\
\text { from 'end day' search }\end{array}$} & \multicolumn{4}{|c|}{$\begin{array}{l}\text { Top } 10 \text { documentary projects from the search 'most } \\
\text { funded' }\end{array}$} \\
\hline & Average & Minimum & Max & $\begin{array}{l}\text { Standard } \\
\text { deviation }\end{array}$ & Average & Minimum & Max & $\begin{array}{l}\text { Standard } \\
\text { deviation }\end{array}$ \\
\hline Actual funding & $\$ 16196.21$ & $\$ 555$ & $\begin{array}{l}\$ 16 \\
3517\end{array}$ & $\$ 37885$ & $\$ 476224$ & $\$ 239020$ & $\$ 1126036$ & $\$ 303684$ \\
\hline $\begin{array}{l}\text { Financial goal } \\
\text { (financial threshold) }\end{array}$ & $\$ 12683.89$ & $\$ 250$ & $\begin{array}{l}\$ 14 \\
3436\end{array}$ & $\$ 33206.85$ & $\$ 303543$ & $\$ 60000$ & $\$ 650000$ & $\$ 210368$ \\
\hline $\begin{array}{l}\text { Ratio: actual } \\
\text { funding/financial } \\
\text { goal }\end{array}$ & 1.52 & 1.04 & 2.6 & 0.52 & 2.02 & 1.10 & 5.4 & 1.3 \\
\hline Number of backers & 164 & 14 & 1685 & 384 & 7074 & 2621 & 16850 & 4169 \\
\hline Funding per a backer & $\$ 89.36$ & $\$ 18.28$ & $\$ 296$ & $\$ 58.94$ & $\$ 72.59$ & $\$ 28.33$ & $\$ 129.61$ & $\$ 31.68$ \\
\hline $\begin{array}{l}\text { Number of new } \\
\text { backers }\end{array}$ & 122 & 2 & 1455 & 327.78 & 3669 & 1254 & 6853 & 1804.63 \\
\hline $\begin{array}{l}\text { Percentage of new } \\
\text { backers }\end{array}$ & $66 \%$ & $10 \%$ & $90 \%$ & $18 \%$ & $57 \%$ & $29 \%$ & $87 \%$ & $21 \%$ \\
\hline
\end{tabular}

Note: the currency of projects varied - there were British pounds, Australian dollars and American dollars. The data in the table is based on calculation of all the projects' funding in American dollars 
funding/aimed financial goal for project'. Therefore, we identified three groups of projects: 'just reach' - ratio 100$119 \%$, 'medium overfunding' - ratio 120-149\%; 'high overfunding' - 150-199\%, and 'exceptional' - ratio above $200 \%$;

c. The numbers of sponsors - the project with 'low numbers of sponsors': 1 to 49; 'medium number of sponsors' - from 50 to 99 supporters; 'high numbers of sponsors' - from 100-199 supporters; 'very high numbers of sponsors' above 200 supporters.

The K-Means analysis indicated six clusters for projects (Tab. III): three clusters for documentary films and three clusters for non-documentary projects. The three clusters of documentary projects are as follows:

- The largest cluster is the group of documentary films which 'just reach' the financial goal with few or relatively few supporters;

- The second cluster of documentary films is the group of projects which 'just reach' the financial goal, but these projects managed to engage high numbers of supporters;
- The third cluster is the group of documentary films which exceeded the level of financing on a medium level and attracted high numbers of supporters;

\section{POLISH FILMMAKERS' VIEWS ON CROWDFUNDING}

\section{A. The methodology of conducting the survey}

In the next phase of research, we asked professionals filmmakers - about their attitude to crowdfunding. A group of 37 professionals (20 women, 17 men) - producers and the students of film production - took part in the survey which aimed to gather information about the barriers for crowdfunding film projects, the preferable structure of the rewards, and future trends on the market. We included the group of students as our respondents due to various reasons: 1. they are likely to seek funding outside the usual procedures, 2. they are likely to implement the Internet in their work, 3. their attitude will impact the development of the film industry as they soon enter (or they have just entered) the film market. In our research we used a

TABLE II.

THE STATISTICS OF ANALYZED PROJECTS - POLAKPOTRAFI.PL AND WSPIERAMKULTURE.PL

\begin{tabular}{|c|c|c|c|c|c|c|}
\hline & \multicolumn{3}{|c|}{$\begin{array}{l}\text { Successful projects on polakpotrafi in film/video } \\
\text { category }\end{array}$} & \multicolumn{3}{|c|}{$\begin{array}{c}\text { Successful project on wspieramkulture.pl in film } \\
\text { category }\end{array}$} \\
\hline & $\begin{array}{c}\text { All } \\
\text { successful } \\
\text { projects in } \\
\text { film } \\
\text { category } \\
\mathrm{N}=108\end{array}$ & $\begin{array}{l}\text { The documentary } \\
\text { films } \\
\text { n (documentary) } \\
=\mathbf{4 1}\end{array}$ & $\begin{array}{c}\text { Non- } \\
\text { documentary } \\
\text { projects } \\
\text { n (non- } \\
\text { documentary) = } \\
67\end{array}$ & $\begin{array}{c}\text { All } \\
\text { projects } \\
\mathrm{N}=\mathbf{2 9}\end{array}$ & $\begin{array}{c}\text { The } \\
\text { documentary } \\
\text { films } \\
n=6\end{array}$ & $\begin{array}{c}\text { Non- } \\
\text { documentary } \\
\text { projects } \\
\mathbf{n}=\mathbf{2 3}\end{array}$ \\
\hline $\begin{array}{l}\text { Average actual } \\
\text { funding per a project }\end{array}$ & zł 10011 & zł 14392 & zł 7329 & zł 8537 & zł 15905 & zł 6615 \\
\hline $\begin{array}{l}\text { Average }- \text { requested } \\
\text { funding (threshold) }\end{array}$ & zł 7737 & zł 10849 & zł 5832 & - & - & - \\
\hline $\begin{array}{l}\text { Minimum actual } \\
\text { funding }\end{array}$ & zł 601 & zł 1401 & zł 601 & zł 510 & zł 850 & zł 510 \\
\hline $\begin{array}{l}\text { Maximum actual } \\
\text { funding }\end{array}$ & zł 58054 & zł 58054 & zł 48365 & zł 36995 & zł 36995 & zł 25205 \\
\hline $\begin{array}{l}\text { Average - number of } \\
\text { sponsors per a project }\end{array}$ & 96 & 133 & 73 & 57 & 127 & 38 \\
\hline \multirow{2}{*}{$\begin{array}{l}\text { Average funding per } \\
\text { sponsor }\end{array}$} & \multirow[t]{2}{*}{ zł 112} & \multirow[t]{2}{*}{ zł 114} & \multirow[t]{2}{*}{ zł 110} & \multicolumn{3}{|c|}{ For projects without 'partner' $(n=21)$} \\
\hline & & & & zł 168 & zł 269 & zł 137 \\
\hline
\end{tabular}

TABLE III.

CluSTERS OF FILM PROJECTS - POLAKPOTARFI.PL

\begin{tabular}{|r|l|l|l|l|l}
\hline & Type of film project & Number of sponsors & The level of funding & Number of cases & Percentage (\%) \\
\hline 1 & Documentary & LOW & JUST REACH & 26 & 24.07 \\
\hline 2 & Documentary & HIGH & JUST REACH & 7 & 6.48 \\
\hline 3 & Documentary & HIGH & MEDIUM OVERFUNDING & 11 & 10.19 \\
\hline 3 & Non-documetnary & LOW & JUST REACH & 39 & 36.11 \\
\hline 5 & Non-documentary & HIGH & HIGH OVERFUNDING & 8 & 7.40 \\
\hline 6 & Non-documentary & MEDIUM & JUST REACH & 17 & 15.74 \\
\hline
\end{tabular}


questionnaire with closed and open questions. The survey was conducted in April, 2016.

\section{$B$. The barriers for film crowdfunding}

The filmmakers' opinions about the barriers were highly diversified. The experts perceived and assessed factors which can hinder the development of crowdfunding differently (see Tab IV). To sum up the filmmakers' responses, we point to the following conclusions:

a. An important barrier in using crowdfunding for film projects lies in the sponsors' uncertainty of the project execution. Over $80 \%$ of experts agreed with the statement that the important barrier for financing film is the sponsors' uncertainty in whether the money would be spent in a reasonable way. Also about $70 \%$ of experts shared the view that sponsors can be uncertain of whether the film would be produced at all.

b. There is no major crowdfunding platform developed exclusively for filmmakers on Polish market (almost $60 \%$ of experts pointed to this barrier).

c. Lack of knowledge about crowdfunding. Half of the group of experts expressed the view that Polish filmmakers lack detailed knowledge about the terms and rules of crowdfunding. Over $60 \%$ of experts claimed that Polish filmmakers do not 'trust' this way of financing film projects.

d. Uncertainty about the legal aspects of crowdfunding. Almost $60 \%$ of experts shared the opinion that the Polish legal regulations for crowdfunding can be perceived as 'vague'.

e. The majority of experts do not perceive that the barriers lie in: 1) the lack of a proper schema of rewards, 2) the high cost of seeking financial support using crowdfunding, or 3) sponsors' concerns about online privacy.

TABLE IV.

EXPERTS' VIEWS OF BARRIERS FOR FILM CROWDFUNDING ON POLISH MARKET

\begin{tabular}{|l|l|c|}
\hline \multicolumn{1}{|c|}{ The stated barrier } & $\begin{array}{c}\text { To what extent the experts agree } \\
\text { with the statement (1-strongly } \\
\text { disagree, 4 -strongly agree) }\end{array}$ & $\begin{array}{c}\text { The percentage of experts } \\
\text { which agree with the statement } \\
\text { (4 or 5 points) }\end{array}$ \\
\hline $\begin{array}{l}\text { The sponsor's uncertainty that the money would be used in a } \\
\text { reasonable way for film production }\end{array}$ & 3.1 & $81 \%$ \\
\hline The sponsor's uncertainty that the film would be produced at all & 3.1 & $68 \%$ \\
\hline $\begin{array}{l}\text { There is no major crowdfunding platform developed for filmmakers } \\
\text { on Polish market }\end{array}$ & 2.8 & $59 \%$ \\
\hline Lack of filmmakers' trust in crowdfunding & 2.7 & $62 \%$ \\
\hline Vague legal regulations for crowdfunding & 2.8 & $59 \%$ \\
\hline Lack of filmmakers' knowledge about crowdfunding & 2.7 & $51 \%$ \\
\hline The prospective sponsors' lack knowledge about crowdfunding & 2.6 & $49 \%$ \\
\hline High costs of crowdfunding for film projects & 2.3 & $41 \%$ \\
\hline $\begin{array}{l}\text { Sponsors' concerns about their privacy and data gathered by } \\
\text { crowdfunding platforms }\end{array}$ & 2.2 & $41 \%$ \\
\hline Too low reward schema for sponsors offered by Polish filmmakers & 2.1 & $30 \%$ \\
\hline
\end{tabular}

TABLE V.

THE FILMMAKERS' ASSESSMENT OF THE REWARD OPTIONS

\begin{tabular}{l|l|l|}
\hline \multicolumn{1}{c|}{ The reward } & $\begin{array}{c}\text { To what extent the reward is } \\
\text { suitable for Polish film market } \\
\mathbf{1}-\text { not suitable at all; } \mathbf{5}-\mathbf{h i g h l y} \\
\text { suitable })\end{array}$ & $\begin{array}{c}\text { The percentage of experts } \\
\text { perceiving the reward schema } \\
\text { as suitable for the Polish film } \\
\text { market }\end{array}$ \\
\hline $\begin{array}{l}\text { Involving backers in events connected with the film, e.g. film premiere, } \\
\text { thank you note on social media website }\end{array}$ & 3.6 & $92 \%$ \\
\hline $\begin{array}{l}\text { The copy of the film on DVD as a reward } \\
\text { phe opportunity for a sponsor to be engaged in film production e.g. }\end{array}$ & 3.4 & $89 \%$ \\
\hline $\begin{array}{l}\text { Film merchandise as rewards, e.g. T-shirts, mugs } \\
\text { Sharing the profit earned by a film project with backers }\end{array}$ & 3.0 & $65 \%$ \\
\hline
\end{tabular}




\section{Developing a reward schema}

In the next part of the survey experts were asked how they perceived different forms of rewarding backers (see Tab. V). The results are:

a. Majority of respondents perceived the following rewards as suitable for film production: involving backers in film events, offering a copy of the film DVD and engaging the supporters directly in the film production process, e.g. playing small parts in the film. The offering film merchandise was perceived as suitable by $65 \%$ of experts.

b. The experts do not agree with the idea of sharing the film profit with backers. Only one third of the experts consider the reward schema based on sharing the film profit with sponsors as a suitable solution on the Polish market.

\section{The experts' views about their involvement in crowdfunding and future trends}

We asked experts the question based on the following scenario: "Imagine that today you are planning the process of film production. To what extent do you consider crowdfunding as a way of funding for your film project?'.

a. Over $90 \%$ of experts - 34 of the 37 respondents - stated that they consider crowdfunding as a supplementary way of funding the film project.

b. Three respondents stated that they would not consider crowdfunding at all.

c. None of respondents aimed to fund the film project mainly with crowdfunding.

The filmmakers also perceived the future role of crowdfunding differently. The group of experts was split almost in half in their assessment.

a. $51 \%$ of respondents agreed with the opinion that during the next five years the importance of crowdfunding for film projects would be growing significantly;

b. $49 \%$ of respondents expressed the opinion that during the next five years crowdfunding still remains only an 'additional' - not significant - way of funding film projects.

The experts also estimated the probability of success of the documentary film project differently.

a. Almost half of respondents $(46 \%)$ stated that documentary films would probably be less successful than other film projects.

b. $24 \%$ of experts estimated the chances of success for documentary films as being similar to other film projects.

c. Almost $30 \%$ of experts perceived the documentary films as being probably more successful than other film projects.

\section{CONCLUSIONS}

This exploratory study, based on the analysis of selected film projects on crowdfunding platforms and the results of a survey conducted among Polish filmmakers, led to the following conclusions:
A.The statistical data indicates that the 'average documentary film' on the Polish market reaches a higher level of funding compared to non-documentary projects, and higher numbers of supporters.

B. The analysis indicates six different clusters of film projects on Polish crowdfunding platforms. Three clusters include documentary film projects:

- first cluster: documentary films 'just reaching' the threshold of funding, with relatively few sponsors;

- second cluster: documentary films 'just reaching' the threshold with a high number of sponsors;

- third cluster: documentary films reaching 'medium level of overfunding' with a high number of sponsors.

Although overfunding may seem be the indicator of film success and, at first glance, has only a positive effect on movie projects, the overfunding of film projects is also linked with possible problems connected with the growing scale of the project (for example, it can change the scale of producing and delivering the film merchandise)

C.The filmmakers taking part in the survey strongly differed in their views about crowdfunding in general, and specifically, the crowdfunding for documentary films. Such diversity of opinions and attitudes may be linked to the novelty of crowdfunding and therefore, the experts' difficulty of assessing the present and future state of crowdfunding.

D.As the majority of film projects are reward-based crowdfunding, it is important for project creators to develop properly working reward options. This study shows that over $85 \%$ of experts agree with the sponsor's involvement with film production. Such high level of expert agreement for sponsor-filmmaker cooperation is important, as one of the major trends of consumer behavior is based on the 'being a prosumer' attitude.

This study is as an exploratory study; therefore, the obtained result is difficult to generalize. However, this exploratory study gives the background for future research, particularly in such areas as:

- building trust between sponsors and founders in crowdfunding for filmmaking;

- the promotional role of crowdfunding and its incorporation in the promotion of a film project;

- the role of crowdfunding in marketing research for the film industry.

\section{REFERENCES}

[1] P. Belleflamme, T. Lambert, and A. Schwienbacher (2014), "Crowdfunding: Tapping the right crowd", Journal of Business

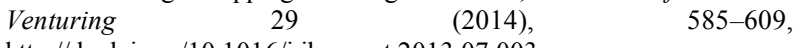
http://dx.doi.org/10.1016/j.jbusvent.2013.07.003

[2] P. Belleflamme, N. Omrani, and M. Peitz (2015), "The economics of crowdfunding platforms", Information Economics and Policy 33 (2015) 11-28, http://dx.doi.org/10.1016/j.infoecopol.2015.08.003

[3] B. Boeuf, J. Darveau, and R. Legoux (2014), "Financing Creativity: Crowdfunding as a New Approach for Theatre Projects", International 
Journal Of Arts Management, Volume 16, Number 3, Spring 2014 33-48

[4] G. Borello, V. De Crescenzo, and F. Pichler (2015), “The Funding Gap and The Role of Financial Return Crowdfunding: Some Evidence From European Platforms", Journal of Internet Banking and Commerce, JIBC April 2015, Vol. 20, No. 1, 1-20

[5] A. Cordova, J. Dolci, and G. Gianfrate (2015), "The determinants of crowdfunding success: evidence from technology projects", Procedia - Social and Behavioral Sciences 181 (2015) 115-124, doi: 10.1016/j.sbspro.2015.04.872

[6] D. Frydrych, A. J. Bock, T. Kinder, and B. Koeck (2014), "Exploring entrepreneurial legitimacy in reward-based crowdfunding", Venture Capital, 2014, Vol. 16, No. 3, 247-269, http://dx.doi.org/ $10.1080 / 13691066.2014 .916512$

[7] P. Galuszka, and V. Bystrov (2014), "Crowdfunding: A Case Study of a New Model of Financing Music Production", Journal of Internet Commerce, 13:233-252, 2014, DOI:10.1080/15332861.2014.961349

[8] J. Hörisch (2015), "Crowdfunding for environmental ventures: an empirical analysis of the influence of environmental orientation on the success of crowdfunding initiatives", Journal of Cleaner Production 107 (2015) 636-645, http://dx.doi.org/10.1016/j.jclepro.2015.05.046

[9] N. Kshetri (2015), "Success of Crowd-based Online Technology in Fundraising: An Institutional Perspective", Journal of International Management 21 (2015) 100-116, http://dx.doi.org/10.1016/ j.intman.2015.03.004

[10] M. Kuti, and G. Madarász (2014/3), “Crowdfunding”, Public Finance Quarterly, 2014/3, 355-366

[11] P. T. I. Lam, and A. O. K. Law (2016), "Crowdfunding for renewable and sustainable energy projects: An exploratory case study approach", Renewable and Sustainable Energy Reviews 60 (2016) 11-20, http://dx.doi.org/10.1016/j.rser.2016.01.046
[12] W. Mendes-Da-Silva, L. Rossoni, B. S. Conte, C. C. Gattaz, and E. R. Francisco (2016), "The impacts of fundraising periods and geographic distance on financing music production via crowdfunding in Brazil", Journal of Cultural Economics (2016) 40:75-99, DOI: 10.1007/s10824-015-9248-3

[13] E. Mollick (2014), "The dynamics of crowdfunding: An exploratory study", Journal of Business Venturing 29 (2014) 1-16, http:// dx.doi.org/10.1016/j.jbusvent.2013.06.005

[14] S. Ryu, and Y.-G. Kim (2016), "A typology of crowdfunding sponsors: Birds of a feather flock together?", Electronic Commerce Research and Applications 16 (2016) 43-54, http://dx.doi.org/10.1016/ j.elerap.2016.01.006

[15] S. Son Turan (2015), "Financial Innovation - Crowdfunding: Friend or Foe?", Procedia - Social and Behavioral Sciences 195 (2015) 353362, doi: 10.1016/j.sbspro.2015.06.334

[16] C. Thürridl, and B. Kamleitner (2016), "What Goes Around Comes Around? Rewards As Strategic Assets In Crowdfunding", California Management Review Vol. 58, No. 2 Winter 2016, 88-110

[17] E. Vasileiadou, J.C.C.M Huijben, and R.P.J.M. Raven (2015), “Three is a crowd? Exploring the potential of crowdfunding for renewable energy in the Netherlands", Journal of Cleaner Production xxx (2015) 1-14, http://dx.doi.org/10.1016/j.jclepro.2015.06.028

[18] B. Xu, H. Zheng, Y. Xu, and T. Wang (2016), "Configurational paths to sponsor satisfaction in crowdfunding", Journal of Business Research $69 \quad$ (2016) 915-927, http://dx.doi.org/10.1016/ j.jbusres.2015.06.040

[19] H. Zheng, D Li., J. Wu, and Y. Xu (2014), "The role of multidimensional social capital in crowdfunding: A comparative study in China and US", Information \& Management 51 (2014) 488-496, http://dx.doi.org/10.1016/j.im.2014.03.003. 